\title{
Russia and Intolerance towards Drug Problems
}

\author{
Maria Lúcia Teixeira Garcia \\ $\mathrm{PhD}$ in Social Psychology \\ Professor in the Department of Social Work and Postgraduate Program in Social Policy at \\ UFES (Federal University of Espírito Santo), Brazil \\ E.mail: lucia-garcia@uol.com.br
}

Doi:10.5296/jsr.v5i1.5648

URL: http://dx.doi.org/10.5296/jsr.v5i1.5648

\begin{abstract}
:
The aim of this article is to examine the problem of drug use in Russia by analysing the direction taken by the drug policies in that country. We conducted an Internet-based literature search using two keywords in English: Russia and drug policy. We began reading the materials identified in the search and organising data. The other sources we used included the websites for the World Health Organization and the Federal Drug Control Service of the Russian Federation. The estimated number of people who use illegal drugs in Russia is five million, and of these, 1.7 million are opiate users. In 2012, approximately 2.5 million Russians were drug-dependent ${ }^{1}$, and $90 \%$ of them used heroin from Afghanistan. With a population of 143 million people, Russia consumes 70 tons of Afghan heroin every year more than one-fifth of the drug consumed globally - according to the United Nations Office on Drugs and Crime. Russian drug policy thus calls the world's attention to what we should not do: focus public policy on actions known to be ineffective for responding to drug use problems.
\end{abstract}

Keywords: Drug policy. Drugs. Russia.

\section{Introduction}

International control of psychotropic substances dates back to the beginning of the twentieth century. Concerned about the high rate of opium consumption at the time and the health consequences of consumption, governments of many countries met (under the North American seal) for the first time to discuss the drug problem at the Shanghai Opium Commission in 1909 (Lima, 2012).

While control over the drug trade and consumption is not a recent development, illegal drug trade activity has gained momentum in the world (and in Brazil), thus requiring actions to

${ }^{1}$ CNPq and Fapes researcher. Research study (no. 485937/2012-3) funded by CNPq Brazilian National Council for Scientific and Technological Development. Member of Fênix group

2 The number of heroin users in countries in Western Europe such as Germany or the United Kingdom is significantly lower - up to 150,000 and 300,000 , respectively, according to several estimates. 
confront it, especially since the 1970s. The prohibitionist model centred on the "war on drugs" discourse was the dominant approach. For Rodrigues (2004), the prohibitionist model that remained in force throughout the twentieth (and beginning of the twenty-first) centuries can only be understood in relation to the imperialist phase of monopolistic capitalism. That is, the author asks us to inscribe the phenomenon in a period of capitalism in which the State is called upon to establish intervention mechanisms to ensure large profits for monopolies and to perform economic functions, such as investing in less profitable sectors and in companies with limited growth potential or in crisis. In other words, the State passes the complexes built with public funds into the hands of monopolies at the expense of costs to the State (Lara, 2009). Alternatively, as indicated by Lênin (1946) and Netto (1996), the main objective of the State is to act as the guarantor of the conditions needed for accumulating and exploiting monopolist capital.

In this context, the world's drug control system is regulated by several Unit Nations Conventions $^{2}$ (the Single Convention on Narcotic Drugs, 1961, amended by the Protocol of 1972; the Convention on Psychotropic Substances of $1971^{3}$; and the Convention Against Illicit Traffic in Narcotic Drugs and Psychotropic Substances of 1978). However, the overall direction of world policy on drugs was set by the United States of America. The U.S., supported by its economic and military power and its hegemonic position in international politics, historically defended a war on drugs as a policy approach.

This "prohibitionist matrix" for drugs, which was developed in the international arena at the beginning of the twentieth century, is divided by Lima (2012) into three large cycles: a) the transnational formation of prohibition ${ }^{4}$, which lasted from the beginning of the twentieth century until World War II (1939-1945), period covering important U.S. foreign security policies such as the Big Stick policy (1904-1933); b) the consolidation of prohibitionism, which lasted from the end of World War II until the end of the Cold War (1947-1989), marked by the arms race, the U.S. declaration of the "war on drugs" and the three current conventions in force for drugs"; and c) criticism of the hegemony of prohibition, which began with the first signs of opposition in the 1980s and continues in the present day, with individuals criticising the effects of drug war policies and beginning to form substitute proposals for the "prohibitionist matrix"

\footnotetext{
2 These treaties have wide membership; in July 2007, 183 States were party to the first two conventions, and 182 were party to the third.

3 The USSR voiced opposition to Article 19 of the Convention (1st and 2nd paragraphs), declaring, "The Union of Soviet Socialist Republics states that the provisions of article 25 of the Convention on Psychotropic Substances, under the terms of which a number of States are not entitled to become Parties to the said Convention, are of a discriminatory nature and considers that in accordance with the principle of the sovereign equality of States, the Convention should be open for participation by all interested States without any discrimination or restrictions. The Union of Soviet Socialist Republics deems it essential to state that the provisions of article 27 of the Convention are at odds with the Declaration on the Granting of Independence to Colonial Countries and Peoples of the United Nations General Assembly (resolution 1514 (XV) of 14 December 1960), which proclaims the necessity of 'bringing to a speedy and unconditional end colonialism in all its forms and manifestations'" (UN, 1971, no page number).

${ }^{4}$ It is important to remember that the use and spread of these substances, such as cocaine and opium, is tied to the World War I period (1914-1918) (RODRIGUES, 2004).

5 I refer to the three conventions in force that are directly related to the theme of drugs, all agreed upon during the Cold War: the Single Convention on Narcotic Drugs from 1961, the Convention on Psychotropic Substances of 1971, the United Nations Convention Against Illicit Traffic in Narcotic Drugs and Psychotropic Substances of 1988, and the Protocol Amending the Single Convention on Narcotic Drugs of 1972.

${ }^{6}$ For example, certain experiences in Europe, the current Uruguayan legislation, the proposal of the state of
} 


\section{Macrothink}

Various authors and non-governmental organisations have denounced the inefficiency and the high cost of current drug policy. During the prohibitionist era, there has been an increase in global rates of violence, an increase in the trafficking of drugs and weapons, strengthening of organised crime tied to drugs, and a strong illicit economy with a significant presence in the financial sector and other sectors of the global economy because of money "laundering" (Fraga, 2009).

It is estimated that the global cost of implementing prohibition is approximately US $\$ 100$ billion per year. At the same time, 300 million people use drugs worldwide, contributing to a world market with sales of US\$330 billion per year (Count the costs, 2011). Del Omo (1992) indicates that the strategies outlined by the USA aimed to: a) eliminate drugs - by reducing production, destroying crops and seizing drugs in both the production and refining processes; b) eliminate traffickers by cracking down and confiscating the assets of narcotraffickers. Neither goal was accomplished, and the volume and diversity of drugs offered and the number of subjects involved in drug trafficking increased ${ }^{7}$.

Moreover:

...public policies aligned with transnational prohibitionism became a channel for profit margins that are difficult to measure, even if the impact of their use on current State expenditures causes heavy losses to the public fund [...] Developing studies on the economy of the illegal drug market and the use of public funding for social policies to fight drugs may help to clarify the political, economic, and financial support base for prohibitionism. The different arguments about the disastrous consequences of drug illegality have not been sufficient to break the geoeconomic and geopolitical defence of the "prohibitionist matrix" but have forced it to coexist with experiences and social policies stemming from human rights and mental health. The coexistence of repressive policies and liberating policies takes place on an unequal playing field, in that the allocation of public resources enhances the coercive actions of the State. This practise enhances the idea that problems with drug use and the illegal drug market require a "harder" or "firmer" intervention from public safety. This unequal combination of policies that depenalise use and policies that categorise non-legitimate drug use as a crime perpetuates the current punitive prohibitionist structure. However, it is necessary to include and tolerate more democratic initiatives in national legislation and policies. However, the punitive axis of prohibitionism continues to be active and dominant with the continuation of the illegal drug market (Lima, 2012, p.284-285, bold added). 
Although difficult to measure, Moreira (2012) indicates that arms trafficking (a process inherent in drug trafficking) moves US\$290 billion/year and drug trafficking moves an additional US $\$ 400$ billion. It is estimated that approximately US $\$ 500$ billion tied to drug trafficking are laundered ${ }^{8}$ and enter the world economy every year.

Drug policy is a complex current topic permeated by information that is not always reliable, but debating drug policy is crucial for questioning and strengthening the struggle to end the "war on drugs". With this ultimate political goal, the aim of this article is to outline the problem of drug consumption in Russia and to analyse the direction of drug policy in that country. Our research question stemmed from the challenge posed by the Fênix Study Group (Grupo de Estudos Fênix) ${ }^{9}$ : what does the drug policy adopted in the world today teach us about Brazilian politics in its most regressive moment (marked by the expansion of measures that harm principles of liberty and autonomy)? I chose to study Russia after a visit to the country in 2012 because I had no information about the drug policies previously implemented there. Previously, I held the classic image of the problem of alcohol abuse ${ }^{10}$.

Like Brazil, Russia is a country that covers a large territory (more than six and a half million square kilometres). The country extends from China and Japan in the east to Europe in the west, spanning 11 time zones. Approximately 142 million people live in Russia, but most of the country is very sparsely populated ${ }^{11}$. The population density is greatest in the western and southern portions of the country.

For this study, we conducted a literature and document review on the Internet using two keywords in English: Russia and drug policy. We began reading the materials we identified and organised the arguments. The other sources we used included the websites of the World Health Organization, the United Nations, the United Nations Office on Drugs and Crime (UNODC) and the Federal Drug Control Service of the Russian Federation, as well as articles available on the Internet.

This paper is organised around three topics: the epidemiology of drug use in the country and the harms associated with this pattern; the drug policies that have been implemented in the country, including the major policy actions in this area; and the lessons that can be learned from these issues in Brazil.

\section{Epidemiological data on drug use in Russia}

When it was a member of the former Union of Soviet Socialist Republics (USSR) ${ }^{12}$, Russia did not significantly participate in the international narcotics market as a consumer of illicit

\footnotetext{
${ }^{8}$ Money laundering consists of a set of commercial or financial operations that aim to incorporate resources, goods and services that originated from or are tied to illicit acts into the economy of a country.

9 The Fênix Study Group on Analysing Public Policies (Grupo de Estudos em Análise de Políticas Públicas Fênix) is tied to the Graduate Program in Social Science at the Federal University of Espírito Santo (Universidade Federal do Espírito Santo - Ufes).

10 The classic image of Boris Yeltsin (the president of Russia in the 1980s) spread worldwide.

11 Brazil has a population slightly greater than 190 million people.

12 The USSR was a socialist country in Europe and Asia that consisted of 15 republics, of which the largest and most important was Russia, with Moscow as the capital.
} 
drugs. During the administration of Mikail Gorbatchev (1985), changes occurred, including the political opening and economic restructuring of the country. The fall of the Berlin Wall (in 1989) and the administrative decision to open the border between East and West Germany affected the countries of the former USSR. The end of Soviet Communism led to the breakup of the Soviet Union, and the former Soviet countries faced a triple crisis: a) an ideological crisis as the leading role played by Communism and the Communist Party of the Soviet Union was challenged when the Community Party was prohibited from all activity after a failed coup in 1991; b) an economic crisis because of the disorganisation of the Soviet economy (inflation, a budget deficit and foreign debt) and the inability to compete in the foreign market); and c) a political crisis marked by the development of "perestroika" and "glasnost", which destabilised Soviet power (Gomes, 2009).

Pari passu with the end of the USSR and the creation of the independent states, data from Paoli (2001) indicate that Russia registered a rapid increase in drug use in the 1990s and was also a transit route for drugs traveling to consumers in Western Europe. The causes of this explosion are deeply rooted in the social and economic changes experienced in the last two decades.

Since 1990, the number of registered drug users has increased by almost 400\%, and in 1999, 359,067 drug users were registered in state drug treatment centres. According to most specialists, however, the true number of drug users is eight to ten times greater.

The Ministry of the Interior estimates that 2.5 - 3 million people regularly or occasionally use illegal drugs in Russia, which represents $2.1 \%$ of the entire Russian population (Audoin; Beyrer, 2012). In absolute terms, this number is not surprising. What is truly notable is the explosion in the use of injection drugs, specifically heroin use. The latter substance became available in Moscow and other Russian cities in the second half of the 1990s and rapidly replaced the homemade opiates previously used by Russian drug users. Today, heroin attracts not only intravenous drug users but also adolescents from all social strata. A study in 1999 indicated that $6 \%$ of interviewed individuals aged 15-16 years old admitted to having used heroin at least one time in their lives (the lifetime rate of use is not greater than $2 \%$ ). The World Health Organization indicates that the annual prevalence of opiate use is $2.3 \%$, and $68.3 \%$ of the 9,263 deaths related to drugs in 2010 were attributed to opiate use (UN, 2012).

Steve Rolles et al (2012) estimate that Brazil, China, Indonesia, Italy, Kenya, Russia, Thailand, USA, Ukraine and Vietnam are responsible for half of the world population of injecting drug users ( 8.1 million) and two-thirds of the people who inject drugs and are living with human immunodeficiency virus - HIV ( 2.1 million). The average prevalence of HIV among people who inject drugs in these countries is approximately $25 \%$, and the prevalence of the hepatitis $\mathrm{C}$ virus (HCV) is as high as $60 \%$. China, Russia and Vietnam have $90 \% \mathrm{HIV} / \mathrm{HCV}$ co-infection rates among injecting drug users.

The data from official agencies indicate that the use of opiates has increased worldwide. This growth is higher in developing countries and nations in transition, whereas opiate use in developed countries is stable or declining. Afghanistan leads the global production of opium; it is responsible for $79 \%$ of total production.

The situation in Russia draws attention from around the world: drug trafficking is growing at a speed unmatched by the rest of the world, but the country does not have suitable treatment 
or prevention programs.

Data from the Russian Federal Service of Narcotics Control indicate that there was a 15-fold increase in the number of crimes related to drugs between 1996 and 2006 and a ten-fold increase in the number of drug users. The number of drug addicts is growing every year: 60,000 in 2005; 70,000 in 2006; and 78,000 in 2007.

Drug addiction costs the Russian economy approximately 1.5 trillion rubles (US $\$ 54$ billion) in losses every year or 2.5\% of the GDP. In 2011, the Russian President Dmitry Medvedev associated drug abuse with the decline in economic growth, justifying the need to adopt restrictive policies, to criminalise drug use and to arrest those who use drugs.

With regard to Russian youth, the data indicate that injection drug use is increasing in addition to alcohol and tobacco abuse. One of the main results is the HIV/AIDS epidemic. In Russia, $80 \%$ of HIV carriers are injection drug users. Of the HIV-positive drug users, 70 to 95\% are youths. Another relevant fact is the number of drug-related incarcerations. With approximately 850,000 inmates, Russia is second in the world with regard to the size of the prison population. An estimated 200,000 to 300,000 of these inmates were arrested for drug possession $^{13}$ (Drug War Chronicle, 2004).

The drug trade has become a serious problem for countries in Central Asia, especially for Tajikistan, which is the main gateway into Russia and neighbouring countries for a continuous flow of drugs from Afghanistan.

The causes of this explosion are deeply rooted in the social and economic changes of recent decades, including the economic crisis that followed the political changes of the 1990s and the expansion of organised crime dedicated to trafficking drugs from neighbouring Afghanistan.

The United Nations (UN) calls attention to the relationship between the U.S. invasion of Afghanistan (2001) and the growth of poppy production (raw material for drugs such as opium and heroin). The area used for cultivation increased by $59 \%$ between 2005 and 2006, and the harvest increased by $49 \%$. It is estimated that $92 \%$ of the heroin circulating in the world is made from Afghan poppies. The drug mainly goes to the European market, but it is also increasingly trafficked to the US, which traditionally received the drug from Colombia.

The explanations for this increase differ. The U.S. government considers the Taliban responsible because the drug trade finances their terrorist actions. The UN believes that most of the profits remain with international organised crime because poppies leave the country and are sold at a relatively low price compared with the amount of money that heroin trafficking moves.

The Canadian Michel Chossudovsky ${ }^{14}$ states (in an article by Marshall, 2008) that reducing poppy production and obtaining control of heroin routes are aspects of the U.S. agenda for the region. "There are powerful businesses and financial interests behind narcotrafficking. Thus, the geopolitical and military control of drug routes is as strategic as that of petroleum and its pipelines". Chossudovsky emphasises that after petroleum and arms trading, the drug

\footnotetext{
${ }^{13}$ As a result of the continuing rise in the prison population in the United States along with a major prisoner amnesty in Russia, the U.S. rate of incarceration surpassed that of Russia in 2000, and the U.S. is now the world leader in imprisonment. The U.S. rate of 699 prisoners per 100,000 population is now greater than the Russian rate, which declined from 730 per 100,000 in 1999 to 644 per 100,000 in 2001.In 2009, the U.S. incarceration rate is almost $20 \%$ higher than second-place Russia (629) (Schmitt, Warner, Gupta, 2010).

${ }_{14}$ President and Director of the Centre for Research on Globalisation.
} 


\section{Macrothink}

trade moves the most money in the world. The researcher recalls that in 2000-2001, the Taliban created a highly successful program to eradicate poppy production. The efforts, which reduced production by $94 \%$, were performed with the help of the UN, which affirms today that the Taliban's action was only to increase the drug's market price. However, the numbers show that the invasion eventually reinvigorated the opium market: the price of opium in 2002 was ten times greater than in 2000.

Another myth challenged by Chossudovsky is that the Taliban benefits the most from heroin trafficking. The UN estimates that the contribution of this trade to the Afghan economy is approximately 2.7 billion dollars. However, only 5\% stays with the Afghan farmers and merchants. Using calculations based on the retail price of heroin, the sale of the drug would bring 124 to 194 billion dollars to Great Britain alone. The Canadian research states that the UN omits the origin of opium production in Afghanistan. Until the invasion of the country by the Soviet Union (1979-1989), poppies were not produced. With the goal of destabilising the Soviet presence, the U.S. Central Intelligence Agency (CIA) had a central role in developing the production of the drug, and the drug money supported the rebel forces. "The Afghan narcotics economy was carefully designed by the CIA, supported by U.S. foreign policy", writes Marshall (2008).

Figure 1. Drug production centres and global drug trafficks

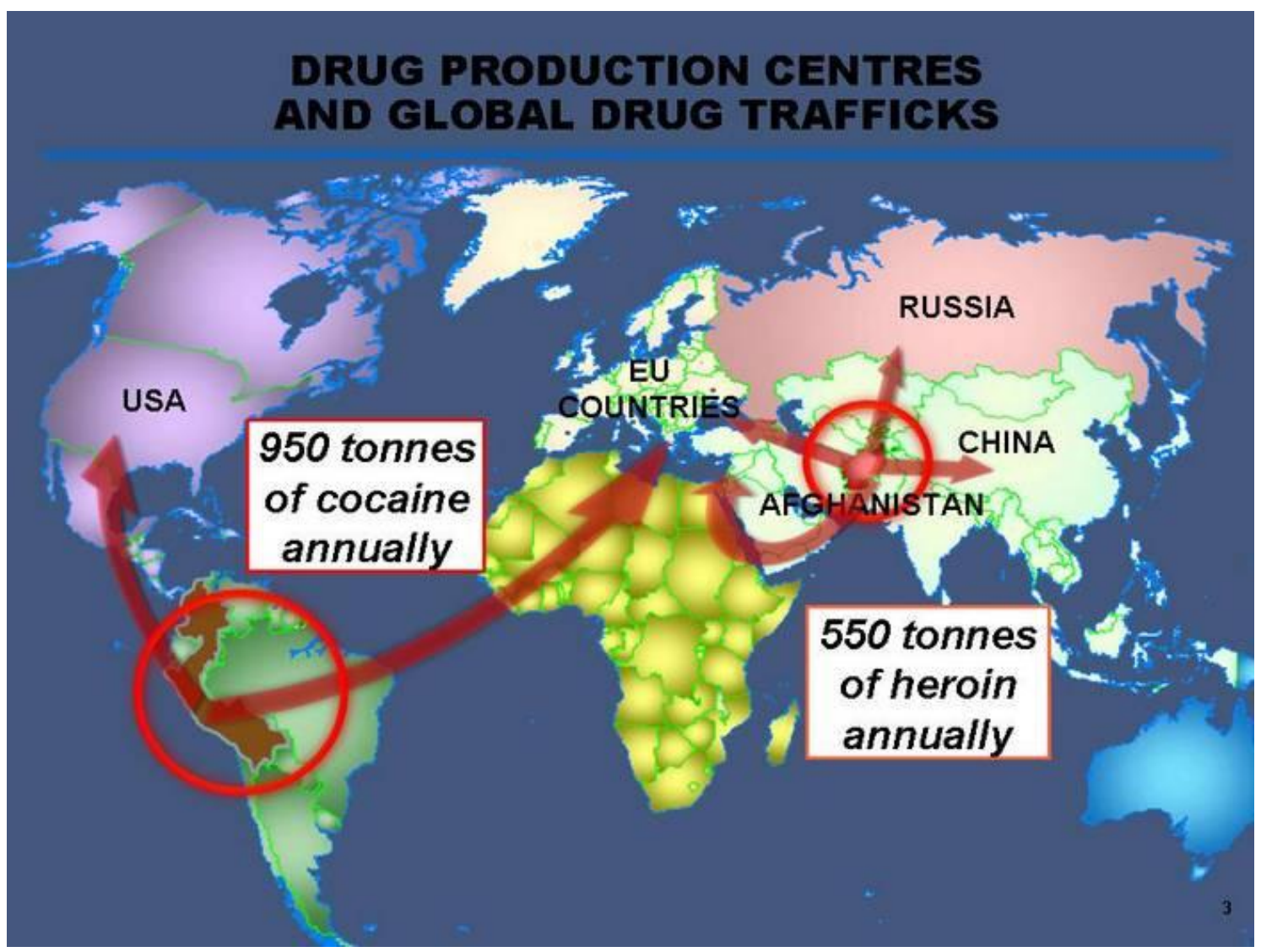

Source: Federal Drug Control Service of the Russian Federation (http://fskn.gov.ru/includes/periodics/eventsmain/2013/0311/125022863/detail.shtml)

According to the "Afghanistan Opium Survey 2012", which was launched in November 2012 by the Islamic Republic of Afghanistan Ministry of Counter Narcotics (MCN) and the United 
Nations Office on Drugs and Crime (UNODC), potential opium production in 2012 was approximately 3.7 thousand tons, which represents an $18 \%$ decline compared with 2001, based on data from the UNODC.

\subsection{Drug use in Russia}

The estimated number of people who use illicit drugs in Russia is five million, and of these, 1.7 million (UN Office on Drugs and Crime, World Drug Report, 2011)) are opiate users ${ }^{15}$. In 2012, approximately 2.5 million Russians were drug addicts ${ }^{16}$, and $90 \%$ of them used heroin from Afghanistan. With a population of 143 million, Russia consumes 70 tons of Afghan heroin every year - more than one-fifth of the amount consumed worldwide according to the United Nations Office on Drugs and Crime.

Nine out of every ten Russians (87\%) identified drug use as a "very serious" problem in Russia today, including 55\% who described the problem as "extremely serious". The only issue that worries Russians more is the corruption that permeates Russian society.

In Russia, heroin kills 80 Russians every day - or 30,000 per year. Meanwhile, new drugs such as highly addictive synthetic marijuana and a cheap, lethal mixture of codeine pills known as "crocodile" - compete with heroin and kill millions of people.

Approximately $32.7 \%$ of injection drug users carry the HIV virus (in some regions, this percentage can reach 75\%). According to the data from the Russian government, approximately $80 \%$ of HIV cases diagnosed between 1987 and 2008 had a direct relationship with the use of injection drugs.

For 59.2\% of the people identified as HIV-positive in 2010, drug use with unsterilised equipment was the main risk factor.

The Russian Ministry of Health considers drug addiction a chronic disease. However, the treatment offered to psychoactive drug users and addicts in Russia is based on policies that do not take the chronic nature of this disease into account. On the contrary, the subjects are subjected to cruel, inhuman or humiliating treatment or punishment. Thus, humiliation and punishment are the methods used for prevention and treatment.

The drug treatment methods accepted for use in Russia are out-dated, and their effectiveness is very low. Although it is internationally recognised and recommended as an effective treatment method for drug dependency, opiate substitution therapy (OST) with methadone and buprenorphine is prohibited by law in Russia. Scientific discussions on substitution therapy are suppressed in Russia under the threat of prosecution (Parfit, 2006).

According to Human Rights Watch, the treatment offered in drug treatment clinics in Russia is precarious and violates the right to health. In their report "Rehabilitation Required: Russia's Human Rights Obligation to Provide Evidence-based Drug Dependence Treatment" (2007), Human Rights Watch concluded that people who are dependent on drugs in Russia and wish to overcome dependency are practically on their own as they battle this serious chronic disease.

The Russian government opposes evidence-based programs aimed at maintaining the health

\footnotetext{
15 Interview with head of the Federal Drug Control Agency, February 4, 2010

16 The number of heroin addicts in countries in Western Europe, such as Germany or the United Kingdom, is significantly lower - up to 150,000 and 300,000 , respectively, according to several estimates.
} 
of drug users and preventing infectious diseases, such as needle and syringe exchange programs. These programs are run by non-governmental organisations without financial help from the government and operate under uncertain legal conditions at the level of policies that are equivalent to condoning drugs.

The Russian State defends the need to build intolerance to drug use. According to the Minister of Health, "the distribution of sterile needles and syringes encourages society to tolerate drug-dependent people and violates the Russian Penal Code." The need to increase "social pressure" against drug users is defended as a method of preventing and combating drug dependency.

Drug use is punishable by imprisonment of up to 15 days. Possession of quantities of opium, heroin or desomorphine above 0.5 grams without the intent to distribute is punished with imprisonment for up to three years.

In 2013, Viktor Ivanov (director of the Federal Service for Control over Drug Trafficking), commenting on the United Nations World Report on Drug Use, stated that Russia should develop a new policy paradigm to combat drugs and drug trafficking and denounced the pressure from some countries to embrace legalisation. For Ivanov, the fight against drug trafficking should be conducted by a well-prepared, honest and competent professional police force.

\section{Russian drug policy}

The government's drug strategy has been subject to questions from around the world. In a speech in 2009, President Medvedev announced certain measures such as performing drug tests on all school-aged children and students in higher education and prohibiting the employment of drug users in occupations that involve the safety of others.

If we consider past policies, there have been several heavily questioned clinical and surgical procedures. For example, beginning in 1998, a Russian research group conducted experimental treatments on opiate addicts. The procedure involved the removal of the "cingulate gyrus", a brain region that has been linked to obsessive compulsive disorder by psychiatrists and neuroscientists ${ }^{17}$ (Medvedev, Anichkov, Polyakov, 2003).

Some defenders of harm reduction blame psychiatrists for the resistance to using methadone programs ${ }^{18}$. The Russian government has developed increasingly stringent public policies on illicit drugs since the early 2000s. In general, the approach criminalises the dependent using law enforcement practises, particularly since the creation of the Federal Drug Control Agency in 2003. In Russia, a person can be imprisoned for a year and a half to overcome injection drug use (Count the costs, 2011).

\subsection{Reducing harm and HIV}

Harm Reduction International indicates that Russia does not have harm reduction policies.

On the one hand, heroin consumption is considered a threat to national security by the Russian government, which finances programs to reduce the harms caused by drug use, including HIV

\footnotetext{
17 This procedure was suspended by the Russian State in 2002.

18 For example, a memorandum in 2005 titled "No to the methadone programs in Russia", published in a medical journal, was signed by the president and vice president of the Russian Society of Psychiatrists.
} 
(one of the most serious health problems in the world) ${ }^{19}$. The increase in HIV incidence is not associated with the absence of public investment - Russia doubled its budget for HIV treatment between 2010 and 2012. However, it is important to examine how the Russian government will use the fund; no resources will be devoted to harm reduction programs. Russia invested approximately US\$600 million in combating HIV in 2012 - double the amount invested in 2010 - but only $3 \%$ of this total was applied to prevention.

The UN states that "harm reduction" program - e.g., needle exchange and the use of methadone as a substitute for heroin - are effective in slowing the spread of HIV. Methadone reduces the risk of infection from dirty needles because it can be swallowed instead of injected. A study conducted by the WHO found a decrease in HIV rates of more than $18 \%$ in cities with needle exchanges while they rose $8 \%$ in areas that did not have them.

Nevertheless, some harm reduction projects are executed in Russia with financial support from the United Nations.

The UN calculates that the number of people living with HIV in Russia is currently more than one million. Beginning in 2004, NGOs in Russia received funding from the UN Global Fund to Combat AIDS, Tuberculosis and Malaria. The funding (US\$351 million) reached half a million Russians. It has supported more than 70 harm reduction programs across the country. However, this funding will no longer be transferred to the programs for two reasons. First, Russia became richer, and the resources from the Fund ${ }^{20}$ will be transferred to poor countries. For rich countries to be eligible for resources from the Global Fund, at least $10 \%$ of the population must be infected (in this case, South Africa is the only country in the group of the 20 richest nations to qualify).

Russia has been a donor and recipient of the Global Fund to Combat AIDS: it has transferred US\$265 million to date. However, the Fund now wants Russia to begin to finance its own harm reduction programs.

However, there has been resistance to these developments. On World AIDS Day, 1 December, a network of "drug users organized protests in 12 Russian embassies around the world" (Koppel, 2012). Hundreds of protestors gathered holding candles, accusing the Russian government of murder for refusing to legalise methadone.

Therefore, Russian policy calls the world's attention to what we should not do: concentrate on actions known to be ineffective (centred in a moral-legal logic) for responding to problems of drug use and disconnect drug use from its economic, political, social and cultural context.

\section{Lessons learned}

The debate on drug policy is experiencing a unique moment. Fifty years after the Single Convention on Drugs (1961), researchers and social organisations have demonstrated the failure of the war on drugs, although the impacts have not been fully evaluated. Despite the fact that the current approach - which aspired to create "a world free of drugs" - has failed, it is estimated that the global costs of implementing prohibition are approximately US $\$ 100$ billion per year. A total of 300 million people use drugs worldwide, contributing to a world

\footnotetext{
${ }^{19}$ The number of HIV positive people in Russia grew 10\% compared with 2011.

${ }^{20}$ Russia has donated US\$265 million to the Fund. The Fund now wants something in exchange: it says that Russia should begin to finance its own harm reduction programs.
} 
economy with a sales volume of US\$330 billion per year (Count the costs, 2011).

The UNODC estimates that approximately 230 million people, or $5 \%$ of the global adult population, used an illegal drug at least once in 2010. Problematic drug users number approximately 27 million, which represents $0.6 \%$ of the global adult population. Worldwide, the use of illicit drugs appears to be stable, although growth continues in several developing countries. Heroin, cocaine and other drugs kill approximately 0.2 million people every year, shattering families and bringing misery to thousands of other people (UNODC, 2013).

Brazil adopted a prohibitionist model that was called moderate by Boiteux (2009), even though the country ratified and implemented all of the international treaties on drug control. We can understand these developments by considering the specific nature of Brazil's socio-historic formation, which is different from the Russian experience. In addition, Brazil and Russia are each experiencing different stages of development. With the important influence of the end of Communism in the former USSR, the current Russian economy and political situation have particularities that must be noted.

Unlike Russian policy, Brazilian law maintains two different control systems that complement each other: penal control regarding trafficking takes the form of classic prohibitionism with high penalties. These offenses are not eligible for bail, interim release or penalty restricting rights because they are treated as heinous crimes by CF/88. For example, Campos (2013) indicates that in 2005 (i.e., prior to the enactment of the New Law on Drugs - Law 11.343 of 2006), there were 32,800 men and women in prison for drug-related crimes (13\%of total prisoners). This number jumped to 133,946 people detained for drugs in 2012 (26\% of the country's total prison population is imprisoned for a crime related to drugs).

On the other hand, law 11.343 provides non-custodial alternatives for drug users. "This model coexists with the official harm reduction policies, although this strategy is not applied broadly in all its forms" (Boiteux, 2009, p. 52).

What does Russia teach us? Confronting questions that involve drug use and trade requires consideration of both global and local policies. As this paper has shown, humanity has coped with the high social costs of Russia's policies. While the prisons around the world overflow with poor addicts and small traffickers, the price of drugs declines, supply and consumption increase and the budget to combat trafficking in a hostile manner multiplies at the expense of taxpayers. Finding alternatives that impose lower costs on citizens should be a goal of any government.

Russian policy therefore calls the world's attention to what we should not do: focus on actions known to be ineffective for responding to the problem of drug consumption.

While various arguments have been based exclusively on the disastrous consequences of drug illegality, we have not been able to "break with the geoeconomic and geopolitical defence of the prohibitionist matrix" (Lima, 2012, p.). What we have achieved thus far is an increase in drug consumption. We need to be critical and creative.

On the one hand, Brazil's perspective and policies have been influenced by the North American prohibitionist matrix. On the other hand, Russia and Brazil have constructed very different paths. Neither of these two countries offers a model for good practices. Both countries need to advance actions that ensure a better approach. Both have faced the issue of 
drugs with different interventions. Whereas the harm reduction strategy is not an alternative policy in Russia, it is in Brazil. In both Russia and Brazil, responsibilities have been transferred to non-governmental organisations. What differentiates them is access to public funding (possible in Brazil but not in Russia).

This is our challenge: to ensure that life is a right in a just society, to ensure that drugs are not the organising centre of moral-legal actions and to recognise the interests of capital in a phenomenon that occurs in the illicit sphere.

\section{References:}

Audoin, B, Beyer, C. Russia's Retrograde Stand on Drug Abuse. Recuperado em: 16 jul. 2010:Available

http://www.nytimes.com/2012/03/03/opinion/russias-retrograde-stand-on-drug-abuse.html?pa gewanted $=$ all\&_r $=0$

Boitex, Luciana. (2009), "Tráfico de Drogas e Constituição: Umestudo jurídico-social do tipo do art. 33 da Lei de Drogas diante dos princípios constitucionais-penais" [Drug Trafficking and the Constitution: A legal-social study of art. 33 of the Law on Drugs given the penal-Constitutional principles]. Cadernos Temáticos da Conseg - Políticas sobre drogas: avanços e Retrocessos [Thematic Books from Conseg - Drug policies: advances and setbacks]. Year 01, nº10. Brasília, Ministério da Justiça.

Count the costs. The War on Drugs: Undermining Human Rights. 2011. Count the costs.

Del Omo (1999), R. Geo politicas de las drogas [Geopolitics of drugs]. Revista Analisis, 1999, no page number.

Drug War Chronicle Russia's New Drug Law in Effect: No Jail for Drug Users, Greater Penalties for Drug Traffickers. $2004 . \quad$ Available: http://stopthedrugwar.org/chronicle-old/328/russia.shtml

Fraga, P. C. Pontes. A geopolítica das drogas na América Latina [Geopolitics of drugs in Latin America]. Em Pauta, n. 19, v. 1, p. 67-88, 2009.

Human Rights Watch. Rehabilitation Required: Russia's Human Rights Obligation to Provide Evidence-based Drug Dependence Treatment. 2007. Available: http://www.hrw.org/sites/default/files/reports/russia1107webwcover.pdf

KoppelL, C. Insight: Russia says no to West's way with HIV. Available: http://www.reuters.com/article/2011/12/21/us-russia-hiv-idUSTRE7BK12X20111221.

Lara, R. A incidência da teoria crítica no Serviço Social [The incidence of critical theory on Social Services]. Serviço Social e Realidade, v. 18, n. 1, p. 43-59, 2009.

Lênin, V.L. Materialismo e empirico-criticismo: notas e críticas sobre uma filosofia reacionária [Materalism and empirio-criticism: notes and criticism on reactionary philosophy]. RJ: Ed. Calvino, 1946.

Lima, RCC. O proibicionismo às drogas: sua periodização e seus marcos transnacionais [Drug prohibitionism: its periodization and transnational landmarks]. In: GARCIA, MLT.; 


\section{Macrothink}

Journal of Sociological Research

ISSN 1948-5468

2014, Vol. 5, No.1

LEAL, F.X. Análise de Políticas Públicas: temas, agendas, processos e produtos [Analysis of Public Policies: themes, agendas, processes and products]. São Paulo: Anablume, 2012, p. 249-288.

Marshall, A.G. Afghan heroin \& the CIA. GeopoliticalMonitor.com. Available at: http://www.geopoliticalmonitor.com/afghan-heroin-the-cia.

MoreiraL.F. Drogas, economia, tributação e a ética liberal [Drugs, economy, taxation and liberal ethics]. Análise Social, n. 204, p. 632-654, 2012.

NettoJ.P. Capitalismo monopolista e Serviço Social [Monopolistic Capitalism and Social Services]. São Paulo: Cortez, 1996.

Paoli, L. Illegal Drug Trade in Russia. A Research Project commissioned by the UN Office for Drug Control and Crime Prevention. Research in brief | forschung aktuell no. 3, Freiburg i. Br. 2001, 21 p.

Rodrigues, T. Política e drogas nas Américas [Politics and drugs in the Americas]. São Paulo: EDUC, 2004.

Steve Rolles, George Murkin, Martin Powell, Danny Kushlick, Jane Slater. The Alternative World Drug Report. 2012. http://www.countthecosts.org/alternative-world-drug-report.

Schmitt, J., Warner, K., Gupta, S. The High Budgetary Cost of Incarceration. Center for Economic and Policy Research, 2010. Available at: http://www.cepr.net/documents/publications/incarceration-2010-06.pdf.

Rensselaer W. Lee and Scott B. MacDonald. Drugs in the East. Foreign Policy 90, Spring 1993.

UNITED NATIONS. 16th Convention on psychotropic substances. Vienna, 1971. Available at:

http://treaties.un.org/Pages/ViewDetails.aspx?src=TREATY\&mtdsg_no=VI-16\&chapter=6\&1 ang=en\#EndDec 